\title{
EFFECT OF STEEL RATIO AND MINERAL ADMIXTURES ON CRUSHING LOAD OF SHORT COLUMNS
}

\author{
K. Chandrika ${ }^{1}$, Ch. Rambabu ${ }^{2}$, T. Chandra Sekhar Rao ${ }^{3}$ \\ ${ }^{1} P G$ scholar, Civil Engineering Department, DMS S.V.H. College of Engineering, Machilipatnam, A.P., India \\ ${ }^{2}$ Associate Professor, Civil Engineering Department, DMS S.V.H. College of Engineering, Machilipatnam, A.P., India \\ ${ }^{3}$ Professor, Civil Engineering Department, Bapatla College of Engineering, Bapatla, A.p., India
}

\begin{abstract}
An experimental study is carried out to investigate the effect of type of lateral reinforcement as a confining material and also the effect of mineral admixtures on compressive strength of concrete in the column composite. For this, the work is carried out in two phases. In the first phase, Short columns were casted by varying volumetric ratio and spacing of lateral reinforcement. The effect of spacing, volumetric ratio on ultimate load carrying capacity of short columns is studied. And in the second phase, Short columns with different types of mineral admixtures like fly ash and GGBS are developed. All the columns were tested in the Universal Testing Machine of $1000 \mathrm{kN}$ capacity. The effect of these admixtures on ultimate load capacity of short columns is studied. Also, modes of failures, crack pattern, stress-strain patterns are also studied in both stages. The test results indicate that with increase in volumetric ratio of steel, the strength and ductility of column increases and the columns in which $20 \%$ GGBS is replaced shows high strength. From the modes of failure it is observed that the short columns shows brittle fracture and zone of rupture is observed at top and bottom ends of the columns and this zone of rupture is decreases with the decrease in spacing of ties. The spacing of ties is strongly influencing zone of rupture in all type of columns is observed in this study.
\end{abstract}

Keywords: Short Column, Volumetric Ratio, Fly Ash, GGBS, Mode of Failure.

\section{INTRODUCTION}

Column is the most authoritative structural element because it carries the entire load of the structure. The failure of the column leads to the total collapse of the whole frame structure as it transmits the vertical loads i.e. loads from roof slab and beam, including self-weight to the foundation. Now-a-days R.C.C. columns are widely used. To achieve overall stability of structures, inelastic deformability of reinforced concrete columns is essential and it is achieved only through proper confinement of the concrete. At the same time, concrete is being used for various constructional purposes to make it suitable for different conditions. In these conditions, ordinary concrete may fail to exhibit the required strength and durability. For this, Admixtures are added in concrete to improve the quality of concrete. Mineral admixtures like fly ash, silica fume, ground granulated blast furnace slag, metakaolin and rice husk ash which possess certain characteristics through which they influence the properties of concrete differently.

\subsection{Advantages of Mineral Admixtures}

The major reasons for using admixtures are:

1. To lower the heat of hydration and thermal shrinkage.

2. To increase the water tightness.

3 . To reduce the alkali - aggregate reaction.

4. To improve resistance to sulphate attacks.

5. To improve extensibility of concrete.

6. To reduce dissolution and leaching.

7. To improve workability.

8. To reduce the cost of concrete construction.
9. To improve the quality of concrete during the different stages of concrete making in various weather conditions.

\subsection{Objectives}

The objectives of this work are:

$>$ To study the load carrying capacity of columns which are confined with different types of lateral reinforcements and with different types of admixtures.

$>$ To study the effect of volumetric ratio on short columns

$>$ To study the crack patterns and modes of failure of short columns.

$>$ To study the zone of rupture in the short columns.

$>$ To study the ductility of columns confined with different types of lateral reinforcements.

$>$ To study load - deflection and stress - strain patterns in the columns.

\section{MATERIALS USED}

- Ordinary Portland cement of 53 grade was used and tested, it was obtained that normal consistency, specific gravity as $28,3.11$.

- Locally available sand was used as fine aggregate and it was confirmed to zone II for which specific gravity is 2.61 and water absorption is $1.8 \%$.

- Crushed stone aggregate of $10 \mathrm{~mm}$ size was used as coarse aggregate and tested for which specific gravity was obtained as 2.75 .

- Potable water free from organic matter, silt, oil, chlorides or acidic material was used for the entire concreting purpose. 
- $6 \mathrm{~mm}$ diameter bars of grade Fe250 are used as longitudinal reinforcement and $4 \mathrm{~mm}$ diameter ties, spiral of grade Fe250 are used as lateral reinforcement.

- The admixtures Fly Ash and GGBS are used for which specific gravities are obtained as 2.67 and 2.81 .

- The moulds having $100 \mathrm{~mm}$ diameter and $600 \mathrm{~mm}$ length which are made with Cast Iron are used for casting of concrete columns.

\section{EXPERIMENTAL PROGRAM}

The present work is mainly focused on studying the effect of type of lateral reinforcement as a confining material and also the effect of mineral admixtures on compressive strength of concrete in the column composite. The short columns of size $100 \mathrm{~mm}$ diameter and $600 \mathrm{~mm}$ length were selected. The short columns were casted and are tested for ultimate load carrying capacity. The above work is carried out in two phases.

First phase of work is targeted to study the effect of load carrying capacity of the short columns, keeping steel ratio of longitudinal reinforcement constant by varying percentage of lateral reinforcement.

Second phase is focused on development of short columns with different types of admixtures and to study the effect of load carrying capacity of columns.

Also the modes of failures, crack pattern, ductility effect and poisons effect are also observed in two phases of work.

\subsection{Phase I}

A total of nine short column specimens had an overall height of $600 \mathrm{~mm}$ with circular cross-section of $100 \mathrm{~mm}$ diameter were casted and tested. They included six circular tied columns and the remaining three are spiral columns. All these nine columns are divided into three series. Three columns are tested for each series.All the details regarding the phase I column specimens are given in Table 1 and Fig. 1.At first, to know the compressive strength of concrete, cube specimens were casted and tested in $1000 \mathrm{kN}$ capacity compression testing machine. The compressive strength after 28 days was recorded as $27.20 \mathrm{~N} / \mathrm{mm}^{2}$.

Table 3.1 Description of Phase I Column Specimens

\begin{tabular}{|c|c|c|c|c|c|c|}
\hline & & \multicolumn{2}{|c|}{$\begin{array}{c}\text { Longitudinal } \\
\text { reinforcement }\end{array}$} & \multicolumn{2}{|c|}{ Transverse reinforcement } \\
\cline { 3 - 7 } $\begin{array}{c}\text { Speci } \\
\text { men }\end{array}$ & $\begin{array}{c}\mathrm{f}_{\mathrm{ck}} \\
\mathrm{MPa}\end{array}$ & $\begin{array}{c}\text { Number } \\
\& \\
\text { diameter, } \\
\mathrm{mm}\end{array}$ & $\begin{array}{c}\rho_{\mathrm{t}} \\
(\%)\end{array}$ & $\begin{array}{c}\text { Dia } \\
\mathrm{mm}\end{array}$ & $\begin{array}{c}\text { Spacing } \\
(\mathrm{s}) \\
\mathrm{mm}\end{array}$ & $\begin{array}{c}\text { Volumet } \\
\text { ric ratio, } \\
\rho_{\mathrm{s}}(\%)\end{array}$ \\
\hline $\begin{array}{c}\text { Series } \\
\mathrm{A}\end{array}$ & 27.2 & $6 \mathrm{No}, 6$ & 1.5 & 4 & 100 & 0.62 \\
\hline $\begin{array}{c}\text { Series } \\
\mathrm{B}\end{array}$ & 27.2 & $6 \mathrm{No}, 6$ & 1.5 & 4 & 30 & 1.57 \\
\hline $\begin{array}{c}\text { Series } \\
\mathrm{C}\end{array}$ & 27.2 & $6 \mathrm{No}, 6$ & 1.5 & 4 & 25 & 2.51 \\
\hline
\end{tabular}
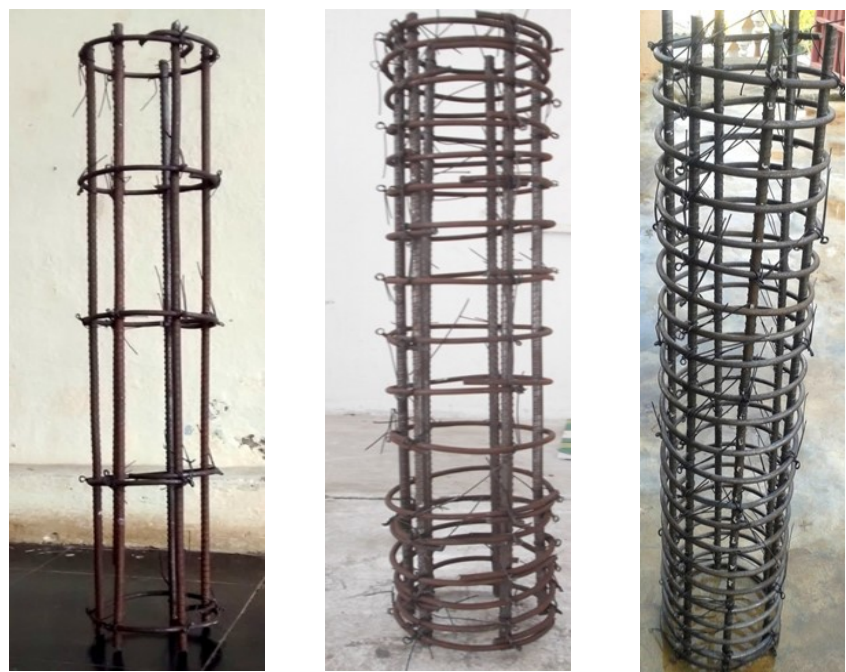

Fig 3.1 Details of confinement of column specimens

\subsection{Phase II}

In this phase, seven sets of column specimens are casted along with control mix (i.e. Series A, AF10, AF20, AF30, AG10, AG20, AG30) and each set consists of three columns. Columns are developed by replacing the cement with different types of admixtures; they are Fly Ash and GGBS. And the control mix column specimen was also casted to compare the remaining columns. The confinement is same for all the set of column specimens. For this, six longitudinal bars of $6 \mathrm{~mm}$ diameter and $4 \mathrm{~mm}$ diameter lateral ties at a spacing of $100 \mathrm{~mm} \mathrm{c} / \mathrm{c}$ are used. The description of these mixes is given in Table 2 below.

Table 3.2 Description of Phase II Column specimens

\begin{tabular}{|c|c|c|}
\hline $\begin{array}{c}\text { Mix } \\
\text { Designation }\end{array}$ & $\begin{array}{c}\text { Replacement of } \\
\text { cement with fly ash } \\
\%\end{array}$ & $\begin{array}{c}\text { Replacement of } \\
\text { cement with GGBS } \\
\%\end{array}$ \\
\hline Series A & 0 & 0 \\
\hline AF10 & 10 & 0 \\
\hline AF20 & 20 & 0 \\
\hline AF30 & 30 & 0 \\
\hline AG10 & 0 & 10 \\
\hline AG20 & 0 & 20 \\
\hline AG30 & 0 & 30 \\
\hline
\end{tabular}

\section{CASTING AND CURING OF SHORT}

\section{COLUMN SPECIMENS}

The fabricated steel confinement were fixed in the steel moulds and provide with cover $15 \mathrm{~mm}$ for top and bottom reinforcement and $10 \mathrm{~mm}$ for concrete. A metal base plate which is having a plane surface is provided at the top and bottom of the mould. The base plate is provided on the mould in such a way that there is no leakage from the mould during the filling and is attached to the mould by means of screws. The parts of the mould are assembled positively and rigidly held together and make it sure during the filling and 
handling of the mould. Mould oil is applied between the sections of the mould, the contact surface between the bottom of the mould and base plate to make it ensure that there is no water leakage during the filling. To prevent adhesion of concrete, the interior surface of the assembled mould has to be thinly coated with mould oil. A steel bar of $16 \mathrm{~mm}$ in diameter, $0.6 \mathrm{~m}$ long and bullet pointed at the lower end serve as a tamping bar.

The casting was carried out in the laboratory. An electric table vibrator was used to consolidate the concrete and to remove air bubbles at each of the lifts. There after the top surface of the column specimen is smoothed using trowel. After 24 hours, the specimens were demoulded and submerged in a water tank for curing. After 28 days the test specimens were removed from the water and left to dry until testing.

\section{TESTING PROCEDURE}

After completing the curing period of the test specimens, all specimens were kept in dry place for few hours for attaining surface dry condition. The columns were placed in the testing rig with $50 \mathrm{~mm}$ thick steel plates at each end of the specimen to distribute the applied load uniformly to the column. The testing was carried out in the loading frame and the compressive load was applied with the hydraulic universal testing machine of capacity $1000 \mathrm{kN}$. Concentric compressive load was applied on all the specimens.

To measure the lateral deflection, a strain gauge of sensitivity $0.002 \mathrm{~mm}$ is provided at the mid height of a column specimen and to measure the longitudinal deflection, a strain gauge of sensitivity $0.002 \mathrm{~mm}$ is provided at the bottom surface of specimen. Gradually the load was applied and the deflection was measured at various load stages at regular intervals, at the same time strain values were also measured and initiation of crack, ultimate load to failure and mode of failure were observed.

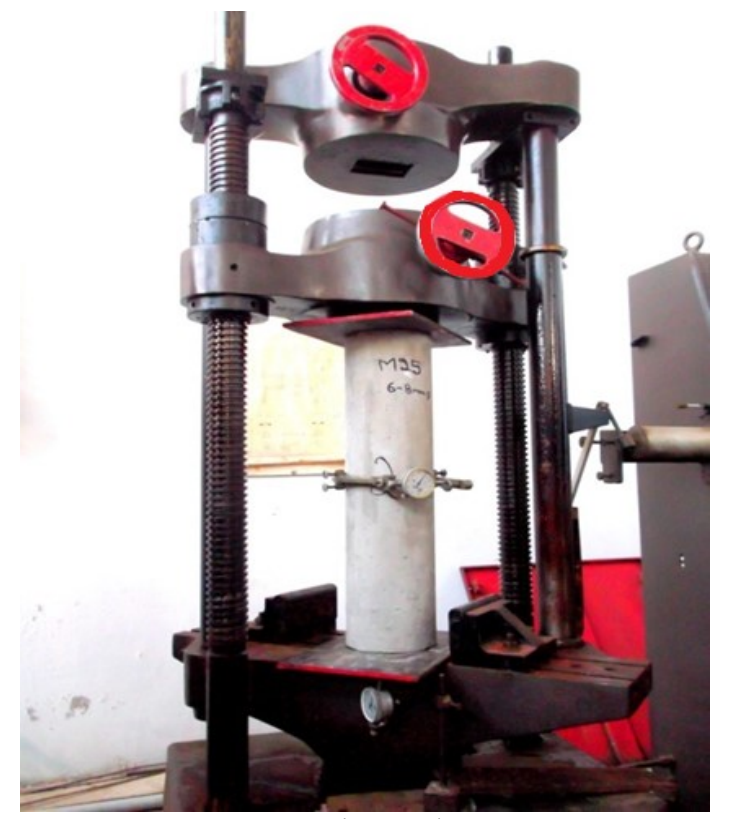

Fig. 5.1 Experimental test set up

\section{TEST RESULTS AND DISCUSSIONS}

\subsection{PHASE I}

Comparative analysis of short column specimens which are confined with different types of confinements is given in table 6.1 and the comparative graph of load carrying capacity of columns is shown in graph 6.1. From the table and graph, it is evident that the ultimate load capacity increases with increase in lateral reinforcement steel and there is a considerable decrease in longitudinal as well as lateral deflections.

Table 6.1 Test Results of Short Columns in Phase I

\begin{tabular}{|c|c|c|c|c|}
\hline Series & $\begin{array}{c}\text { First } \\
\text { Crack } \\
\text { load } \\
(\mathrm{kN})\end{array}$ & $\begin{array}{c}\text { Ultimate } \\
\text { load } \\
\text { capacity } \\
(\mathrm{kN})\end{array}$ & $\begin{array}{c}\text { Longitudinal } \\
\text { deflection } \\
(\mathrm{mm})\end{array}$ & $\begin{array}{c}\text { Lateral } \\
\text { deflection } \\
(\mathrm{mm})\end{array}$ \\
\hline $\mathrm{A}$ & 61.00 & 134.90 & 5.27 & 3.30 \\
\hline $\mathrm{B}$ & 88.60 & 175.60 & 3.32 & 2.86 \\
\hline $\mathrm{C}$ & 90.25 & 195.25 & 1.17 & 1.25 \\
\hline
\end{tabular}

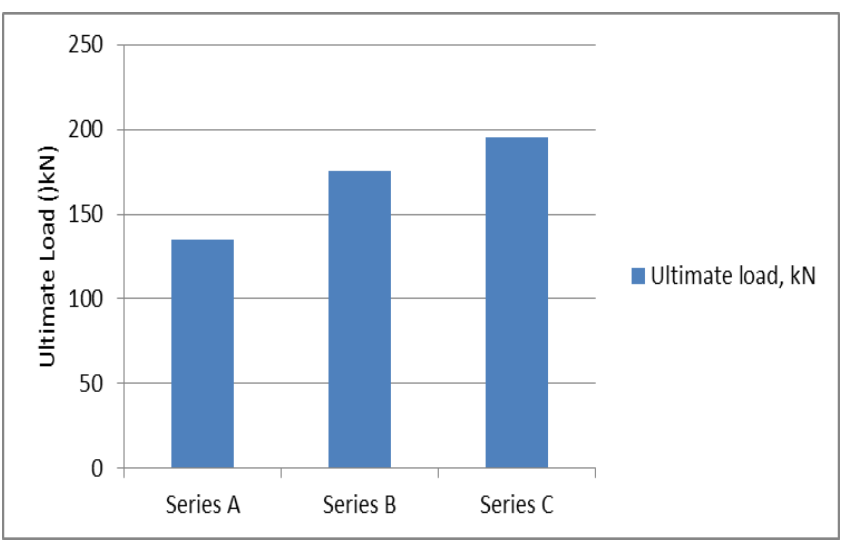

Graph 6.1 Comparative graph of load carrying capacity of short columns in phase I

\subsubsection{Modes of failure}

In case of short column which fail in compression shows the brittle fracture. The zone of rupture in short columns was observed near one-fourth height from top of the column for series A. But this length reduces to one-sixth for series B and one - ninth for series C columns. The first crack appeared near the corner and propagated vertically, thereby separating the mortar layer from the core concrete followed by failure of column. The mode of failure and crack patterns are shown in fig 6.1 


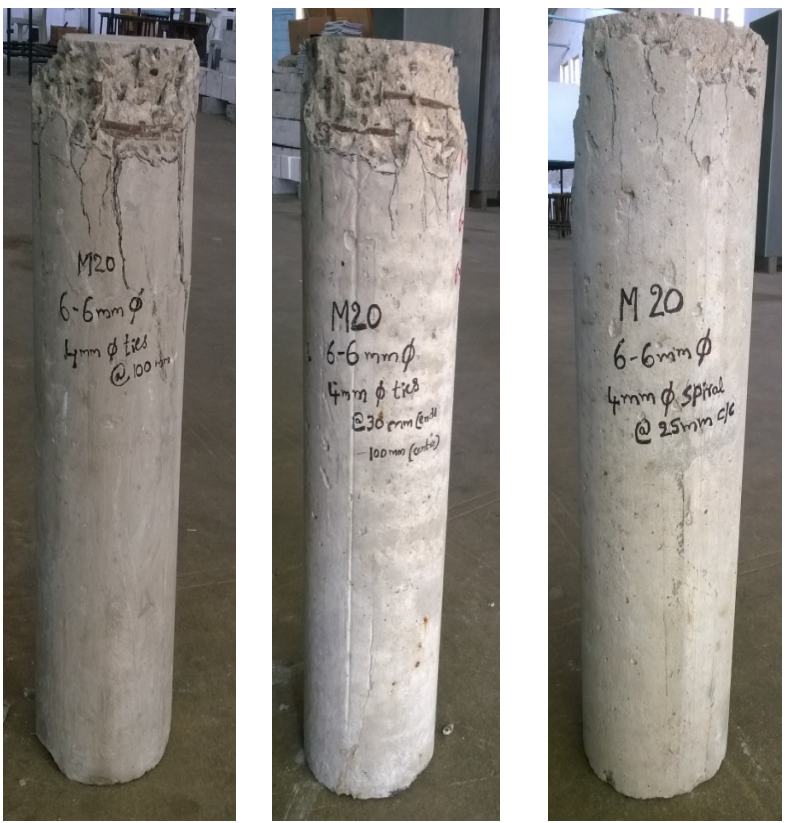

Fig 6.1 Modes of failure of short columns in phase I

\subsubsection{Stress - Strain Curve}

A comparative study is carried out to evaluate the capabilities of various confinement models of short columns. The comparative stress-strain curve is drawn for three sets of columns which are given in graph 6.2. It shows that all the models are estimate correctly that they show ascending part of stress-strain curve and the strain taken by the spiral reinforced column is less compared to other series of columns.

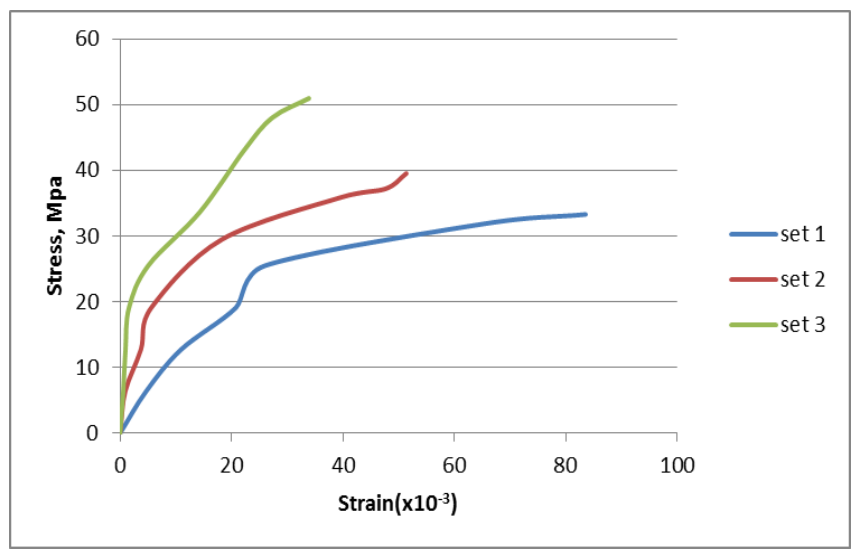

Graph 6.2 Comparative stress - strain curve of short columns in phase I

\subsubsection{Effect of Lateral Reinforcement on Ductility of}

\section{Short Columns}

Ductility of a structure is defined as its ability to undergo deformation beyond the initial yield deformation under sustained load. Ductility characterizes the deformation capacity of members after yielding, or their ability to dissipate energy.

The ductile behavior of columns is increases with the decrease in spacing of lateral ties. A measure of ductility of the structures may be expressed by ductility factor. Ductility factor may be defined as the ratio maximum lateral deflection at any load level or at the end of the post elastic range to lateral deflection when first yield is reached. This factor is also known as displacement ductility factor which is given as

Ductility factor $=\mu=\frac{\delta_{\mathrm{u}}}{\delta_{\mathrm{y}}}$

The ductility factors for the three series of short columns corresponding to their loads and deflections are given in table 6.2

Table 6.2 Ductility factors of phase I short columns

\begin{tabular}{|c|c|c|c|c|c|}
\hline $\begin{array}{c}\text { Serie } \\
\mathrm{S}\end{array}$ & $\begin{array}{c}\text { Yield } \\
\text { load } \\
(\mathrm{kN})\end{array}$ & $\begin{array}{c}\text { Yield } \\
\text { deflect } \\
\text { ion } \\
\delta_{\mathrm{y}} \\
(\mathrm{mm})\end{array}$ & $\begin{array}{c}\text { Ultimat } \\
\text { e load } \\
(\mathrm{kN})\end{array}$ & $\begin{array}{c}\text { Ultimate } \\
\text { deflectio } \\
\mathrm{n} \\
\delta_{\mathrm{u}}(\mathrm{mm})\end{array}$ & $\begin{array}{c}\text { Ductilit } \\
\mathrm{y} \\
\text { factor } \\
\mu=\frac{\overline{\mathbf{b}}_{\mathrm{u}}}{\overline{\mathbf{s}}_{\mathrm{y}}}\end{array}$ \\
\hline $\mathrm{A}$ & 61.00 & 2.1 & 134.90 & 3.30 & 1.57 \\
\hline $\mathrm{B}$ & 88.60 & 1.2 & 175.60 & 2.86 & 2.39 \\
\hline $\mathrm{C}$ & 90.25 & 0.79 & 195.25 & 1.25 & 2.42 \\
\hline
\end{tabular}

From the above table it was evident that the ductility factors are increasing with increasing in lateral reinforcement steel and Series C column which is confined with spiral reinforcement shows ductility increment for about 54\% compared to Series A columns in which ties are equally placed

\subsubsection{Effect of volumetric ratio and spacing of lateral Steel}

With increase in the volumetric ratio of lateral confinement, the increase in lateral confining pressure is increases. Also, the spacing in lateral steel is important parameter that directly affects the distribution of confinement pressure on the concrete core in addition to the stability of the concrete. The ductile behavior of columns is increases with the decrease in spacing of lateral ties. The columns with low volumetric ratio or increased spacing of lateral steel exhibit brittle behavior, showing faster rate of strength decrement.

\subsection{PHASE II}

Comparative analysis of short column specimens in which cement is replaced with different types of mineral admixtures is given in table 6.3and the comparative graph of load carrying capacity of short columns is shown in graph 6.3. From the table and graph, it is evident that the short column specimen (AG20) in which cement is replaced with $20 \%$ of GGBS shows maximum ultimate load capacity i.e. $179.80 \mathrm{kN}$. And also the longitudinal and lateral deflections are less compared to the other specimens. 
Table 6.3 Test results of short columns in phase II

\begin{tabular}{|c|c|c|c|c|}
\hline Mix & $\begin{array}{c}\text { First } \\
\text { crack } \\
\text { load } \\
(\mathrm{kN})\end{array}$ & $\begin{array}{c}\text { Ultimate } \\
\text { load } \\
\text { capacity } \\
(\mathrm{kN})\end{array}$ & $\begin{array}{c}\text { Longitudinal } \\
\text { deflection } \\
(\mathrm{mm})\end{array}$ & $\begin{array}{c}\text { Lateral } \\
\text { deflection } \\
(\mathrm{mm})\end{array}$ \\
\hline $\begin{array}{c}\text { A Series } \\
(\mathrm{CM})\end{array}$ & 64 & 134.90 & 5.27 & 3.30 \\
\hline $\begin{array}{c}\text { AF10 } \\
(\mathrm{FA} \mathrm{10 \% )}\end{array}$ & 85 & 156.30 & 5.20 & 2.90 \\
\hline $\begin{array}{c}\mathrm{AF} 20 \\
(\mathrm{FA} \mathrm{20 \% )}\end{array}$ & 92 & 177.85 & 4.28 & 2.50 \\
\hline $\begin{array}{c}\text { AF30 } \\
(\mathrm{FA} \mathrm{30 \% )}\end{array}$ & 78 & 140.20 & 5.40 & 3.50 \\
\hline $\begin{array}{c}\text { AG10 } \\
(\mathrm{GG} \mathrm{10 \% )}\end{array}$ & 84 & 158.25 & 4.85 & 2.52 \\
\hline $\begin{array}{c}\text { AG20 } \\
(\mathrm{GG} \mathrm{20 \% )}\end{array}$ & 95 & 179.80 & 4.26 & 2.42 \\
\hline $\begin{array}{c}\text { AG30 } \\
(\mathrm{GG} \mathrm{30 \% )}\end{array}$ & 67 & 125.20 & 7.50 & 4.20 \\
\hline
\end{tabular}

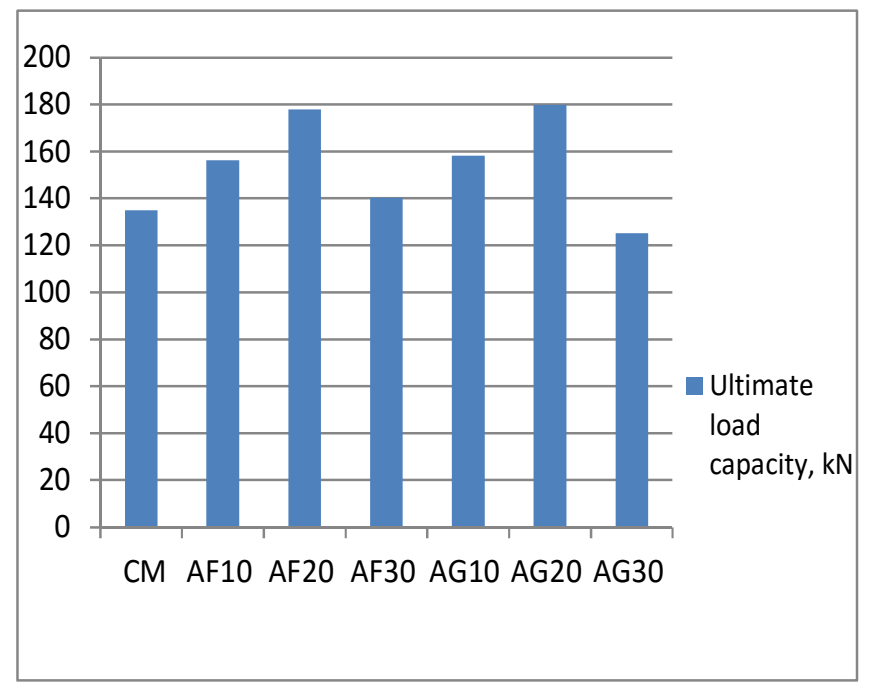

Graph 6.3 Comparative graph of load carrying capacity of short columns in phase II

\subsubsection{Modes of failure}

In case of short column, which fail in compression shows the brittle fracture. The zone of rupture in short columns was observed near one-fourth height of the column either from top or bottom. The first crack appeared near the corner and propagated vertically, thereby separating the mortar layer from the core concrete followed by failure of column. The mode of failure and crack pattern are shown in fig. 6.2

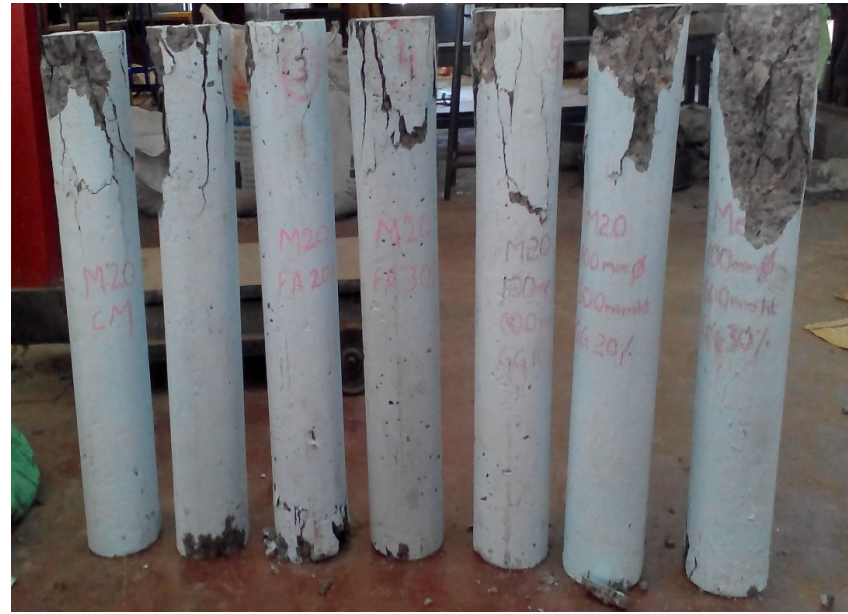

Fig 6.2 Modes of failure of short columns in phase II

\subsubsection{Stress - strain curve}

A comparative study is carried out to evaluate the capabilities of various confinement models of short columns. The comparative stress-strain curve is drawn for three sets of columns which is given in graph 6.4. It shows that all the models are estimate correctly that they show ascending part of stress-strain curve.

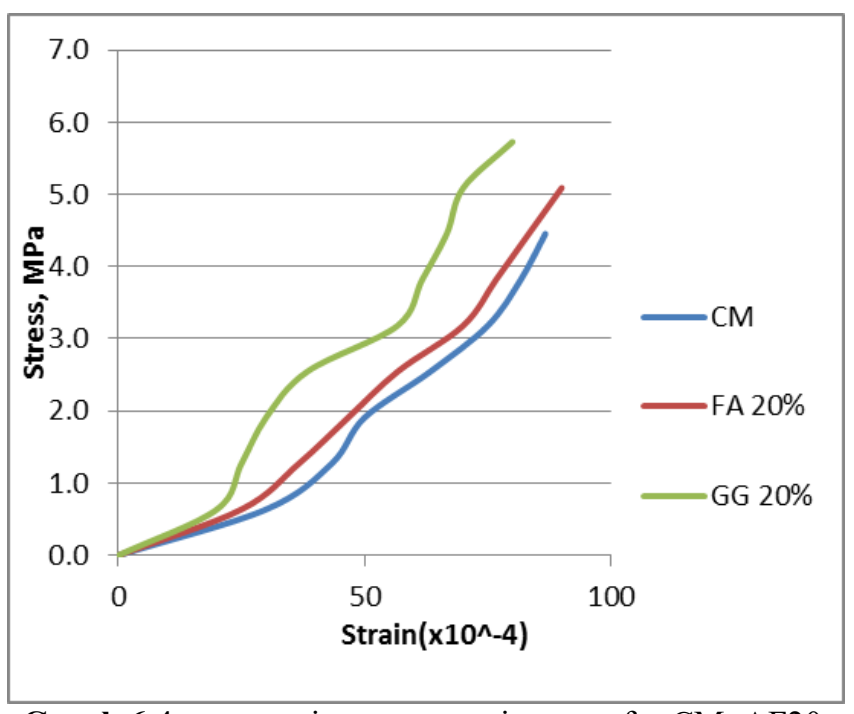

Graph 6.4 comparative stress-strain curve for CM, AF20, AG20

\section{CONCLUSIONS}

- The load carrying capacity of the columns increases with increase in lateral reinforcement.

- The short columns which are laterally confined with spiral reinforcement show highest load carrying capacity and shows lowest longitudinal as well as lateral deflection compared to other series of columns.

- The ductility of short columns increases with increase in ductility factor of short columns i.e. the columns which are confined with spiral shows good ductility.

- The column in which cement is replaced with $20 \%$ of GGBS i.e. AG20 shows highest load carrying capacity and also show lowest longitudinal and lateral deflection. 
- From the mode of failure of columns it was observed that the longitudinal cracks are formed at the top and bottom ends of the short columns.

- The zone of rupture is observed near one-fourth height of the column either from top and bottom for series A, this length decreases with decrease in spacing of lateral reinforcement.

- From the comparative stress-strain curves, it was observed that the strain taken by the spiral reinforced column and GGBS $20 \%$ column is less compared to other set of columns.

\section{REFERENCES}

[1] Umesh K. Sharma, Pradeep Bhargava and S.K.Kaushik. "Behavior of Confined High Strength Concrete Columns Under Axial Loaded". Asian Journal of advanced concrete technology Vol.3, No.2, (2005), Pages 267-281.

[2] Shafqat A \& Ali A. A study on "Lateral Confinement of RC Short Column". Journal of ISSN 1013-5316, vol.24, no 4, pages 371-379.

[3] Antonius. A. "Studies on the provisions of confining reinforcement for high strength concrete column". 2nd International Conference on Sustainable Civil Engineering Structures and Construction Materials 2014 (SCESCM 2014).

[4] A. Alqatamin1 A. Talposi. "The Action of Short Columns at Reinforced Concrete Building Constructions". Bulletin of the Transilvania University of Brasov, Vol. 2 (51) - 2009, and Series I.

[5] B.G. Vishnuram, K. Subramanian, P. Muthupriya. "Experimental Investigation On High Performance Reinforced Concrete Column With Silica Fume And Fly Ash As Admixtures", Asian Journal of Civil Engineering (Building and Housing) Vol.12, No.5 (2011), Pages 597-618.

[6] P. Muthupriya, Dr. K. Subramanian, B.G. Vishnuram. "Investigation On Behavior of High Performance Reinforced Concrete Columns With Metakaolin And Fly Ash as Admixture", International Journal of Advanced Engineering Technology E-ISSN 09763945, Vol. II, Issue I, January-March (2011), pages 190-202.

[7] Sadaqat Ullah Khan, Muhammad Fadhil Nuruddin, Tehmina Ayub, and NasirShafiq. "Effects of Different Mineral Admixtures on the Properties of Fresh Concrete “, Scientific World Journal, Volume 2014, 11 Pages.

[8] K. Gurunaathan and G. S. Thirugnanam. "Effect of Mineral Admixtures on Durability Properties of Concrete", International Journal of Advanced Structures and Geotechnical Engineering ISSN 23195347, Vol. 03, No. 01, January 2014.

[9] M. Ramalekshmi, R. Sheeja, R. Gopinath. "Experimental Behavior of Reinforced Concrete with Partial Replacement of Cement with Ground Granulated Blast furnace Slag”. International Journal of Engineering Research \& Technology (IJERT), ISSN: 2278-0181, Vol. 3 Issue 3, March - 2014.
[10] A. Annadurail and A. Ravichandran. "Flexural Behavior Of Hybrid Fiber Reinforced High Strength Concrete", Indian Journal of Science and Technology, Vol 9(1), January 2016.

[11] Foster. S.J. "Design and Ductiling of High Strength Concrete Columns", Research report No. R375, University of New South Wales, Sydney, Australia (1999).

[12] SHETTY. M.S, Concrete Technology - theory and practice. IS 456 - 2000 